\title{
Properties of Liquid and Polycondensed UF Resin Modified with pMDI
}

\section{Svojstva tekuće i polikondenzirane UF smole modificirane s pMDI}

\author{
Original scientific paper • Izvorni znanstveni rad \\ Received-prispjelo: 4. 4. 2013. \\ Accepted-prihvaćeno: 9. 4. 2014. \\ UDK: $630 * 861.156$ \\ doi:10.5552/drind.2014.1321
}

\begin{abstract}
The aim of this study was to determine the properties of liquid and cured UF (urea-formaldehyde) resin modified with pMDI (polymeric 4, 4'-methylenediphenyl isocyanate). Analyses showed that when introduced to liquid UF resin already at $10 \%$, its reactivity increases, which is reflected in a shortening of gel time and reduction of activation energy of the polycondensation process. In turn, analyses performed on polycondensed resin showed that, thanks to modification with pMDI, its hydrophobicity is considerably improved, as manifested in a reduction of absorbability and swelling in thickness of cured resin.
\end{abstract}

Key words: UF, pMDI, hybrid resin, FTIR, hydrophobicity

SAŽETAK • Cilj istraživanja bio je utvrditi svojstva tekuće i otvrdnute UF smole (urea-formaldehida) modificirane s pMDI-jem (polimernim 4, 4'-metilendifenil izocijanatom). Analiza je pokazala da dodavanjem pMDI-ja tekućoj UF smoli već u $10 \%$-tnoj količini rezultira povećanjem reaktivnosti, izraženoj skraćivanjem vremena želiranja i smanjenjem energije aktiviranja procesa polikondenzacije. Osim toga, analiza svojstava polikondenzirane smole pokazala je da je, zahvaljujući modifikaciji s pMDI-jem, znatno poboljšana hidrofobnost, što se očituje smanjenjem apsorpcije i bubrenja otvrdnute smole u debljinu.

Ključne riječi: $U F$, pMDI, hibridni smole, FTIR, hidrofobnost

\section{INTRODUCTION \\ 1. UVOD}

In order to improve water resistance of urea-formaldehyde resin (UF), an adhesive, commonly used in the manufacture of wood-based materials, is modified first with water resistant melamine-formaldehyde (MF) or phenol-formaldehyde (PF) adhesives. Despite their obvious advantages, a combined melamine-urea-phenol-formaldehyde (MUPF) resin does not completely exhibit the advantageous properties of its individual components, particularly in terms of resistance to the action of variable ambient conditions (Cremonini et al., 1996a; Kamoun and Pizzi, 1998; Prestifilippo and Pizzi, 1996; Prestifilippo et al., 1996; Tomita and Hse, 1992; Tomita et al., 1995; Weinstabl et al., 2001). As a result, wood based materials manufactured with its use have lower water resistance than when produced using pure PF resin. For this reason, MUPF resins are applied in the production of plywood and construction boards with enhanced resistance only to the action of variable weather conditions (Cremonini and Pizzi, 1999; Cremonini et al., 1996b, 1996; Zhao and Pizzi, 2000).

Another direction leading to an enhancement of water resistance in amine resins is their modification with pMDI (polymeric 4, 4'-methylenediphenyl isocy-

\footnotetext{
Authors are assistant professors at Faculty of Wood Technology, Poznań University of Life Sciences, Poznań, Poland.

Autori su docenti Fakulteta drvne tehnologije Sveučilišta bioloških znanosti u Poznanju, Poznanj, Poljska.
} 
anate) (Pizzi et al., 1993; Osman et al., 2005; Mansouri et al., 2006; Lei et al., 2006). Analyses showed that a $40 \%$ addition of isocyanates to UF resin makes it possible to manufacture plywood with an even better water resistance than that specified in the respective standard binding for MF resin (Pizzi et al., 1993). In turn, the use of UF/pMDI hybrid adhesive, thanks to a reduction of the pMDI share to $15 \%$, reduces the costs and improves its water resistance, but only to a limited extent. Plywood produced with this adhesive exhibited good water resistance only after 27 min of boiling instead of $2 \mathrm{~h}$, as specified in the standard for melaminebased resin (Mansouri et al., 2006). In contrast, Lei et al. (2006) stated that an addition of pMDI to MUPF resin generally did not improve mechanical properties, but it considerably improved the board water resistance. These researchers showed that, when pMDI is added to MUPF resin at as little as $5 \%$ tensile strength of particleboards, after $2 \mathrm{~h}$ boiling the water resistance increases from 0.09 to $0.21 \mathrm{~N} / \mathrm{mm}^{2}$. The presented modification method of amine resins, apart from an increase in water resistance, also contributes to a reduction of costs associated with pMDI use.

This study analyzed the basic properties of liquid and polycondensed UF resin modified with pMDI.

\section{MATERIALS AND METHODS}

\section{MATERIJAL I METODE}

Analyses were performed on UF resin and pMDI, commonly applied in the wood based material industry to manufacture materials used indoors and outdoors. The basic properties of resins used in the study are shown in Table 1.

Table 1 Properties of liquid pure resins used in the study Tablica 1. Svojstva čiste tekuće smole upotrijebljene u istraživanju

\begin{tabular}{|c|c|c|}
\hline $\begin{array}{l}\text { Determined parameter } \\
\text { Svojstvo }\end{array}$ & pMDI & UF \\
\hline $\begin{array}{l}\text { No. } 4 \text { Ford cup viscosity, } \mathrm{s} \\
\text { viskoznost prema Fordu, s }\end{array}$ & - & 89 \\
\hline $\begin{array}{l}\text { Viscosity at } 25^{\circ} \mathrm{C}, \mathrm{mPa} \cdot \mathrm{s} \\
\text { viskoznost pri } 25^{\circ} \mathrm{C}, \mathrm{mPa} \cdot \mathrm{s}\end{array}$ & 215 & - \\
\hline $\begin{array}{l}\text { Density at } 20^{\circ} \mathrm{C}, \mathrm{g} / \mathrm{cm}^{3} \\
\text { gustoća pri } 20^{\circ} \mathrm{C}, \mathrm{g} / \mathrm{cm}^{3}\end{array}$ & - & 1.282 \\
\hline $\begin{array}{l}\text { Solids content, \% } \\
\text { sadržaj suhe tvari, \% }\end{array}$ & 100 & 65.0 \\
\hline $\mathrm{pH}$ & - & 8.2 \\
\hline $\begin{array}{l}\text { Hydrolytic chlorine, } \mathrm{mg} \cdot \mathrm{kg}^{-1} \\
\text { hidrolitički klor, } \mathrm{mg} \cdot \mathrm{kg}^{-1}\end{array}$ & 96 & - \\
\hline $\begin{array}{l}\text { Gel time at } 100^{\circ} \mathrm{C}, \mathrm{s} \\
\text { vrijeme želiranja pri } 100^{\circ} \mathrm{C}, \mathrm{s}\end{array}$ & - & 75 \\
\hline $\begin{array}{l}\text { Miscibility with water, } \mathrm{cm}^{3} / \mathrm{g} \\
\text { mješljivost } s \text { vodom, } \mathrm{cm}^{3} / \mathrm{g}\end{array}$ & - & 1.4 \\
\hline NCO content, \% / sadržaj NCO, \% & 30.9 & - \\
\hline
\end{tabular}

pMDI was used as a UF resin modifier, introduced at $10 \%$ in relation to the urea resin solution weight. In the case of liquid hybrid resin (UF/pMDI), its viscosity was determined by measuring flow time with a Ford's cup and gel times within the temperature range of $80,90,100$ and $110^{\circ} \mathrm{C}$, based on which relative activation energy of the cross-linking process was calculated (Wang et al., 1995). It was assumed that the curve illustrating the curing process in time, at specific temperatures of $80,90,100$ and $110^{\circ} \mathrm{C}$, was a linear function till the curing point was reached. Since the reaction rate increases with the rise in temperature, and the curve illustrating the curing rate depending on the inverse of the absolute temperature shows a very good linear correlation, the activation energy $\left(E_{\mathrm{a}}\right)$ can be calculated based on the Arrhenius equation:

$$
k=A \cdot e^{-E a / R \cdot T}
$$

where $k$ means the curing reaction rate constant, $A$ is the pre-exponential factor, $R$ is the gas constant and $T$ is the absolute temperature.

After transformation, the Arrhenius equation acquires the form:

$$
\ln k=\ln A-\left(E_{a} / R\right) \cdot 1 / T
$$

The activation energy has been determined by graphical method. For this purpose, the course of dependence $R \times \ln k$ on $1 / T$ has been analyzed. In accordance with this method, the activation energy $E_{a}$ is equal to the coefficient of the slope of the line $R \times \ln k=f(1 / T)$ and $1 / T=0$ is equal $\ln A$ (Proszyk et al., 1996).

Sample preparation methodology for these analyses was presented in a study by Dziurka and Łęcka (2004).

In contrast, the content of water-leached substances, absorbability and swelling in length were determined for the polycondensed pMDI-amine resin mixture. On the basis of these properties, inferences may be made on the course of polycondensation. Additionally, infrared spectroscopy was applied in order to clarify the effect of pMDI on the chemical structure of cured hybrid UF/pMDI resin. Since the IR spectrum is highly characteristic of these substances, it may be treated as an analytical tool for the identification of structural groups present in tested compounds, as well as for analyses of occurring chemical processes.

The samples for the analyses contained pMDI and $10 \%$ (by weight) of UF resin were cured at $120^{\circ} \mathrm{C}$ for $24 \mathrm{~h}$ in a glass tube of $0.5 \mathrm{~cm}$ in diameter. Thus cured samples were next comminuted in an impact mill and sieved at mesh size of $0.25,0.2$ and $0.125 \mathrm{~mm}$ or cut into samples of $18 \mathrm{~mm}$ in length. Further analyses, in case of substances leachable with water, FTIR spectroscopy and formaldehyde content determinations were conducted on the fraction left on the sieve with mesh size of $0.2 \mathrm{~mm}$.

The amount of substances leachable with water from polycondensed resin was determined based on the loss of weight in comminuted resin after $24 \mathrm{~h}$ soaking in water. The perforator method was used to measure formaldehyde content in accordance with the standard PN-EN 120. In order to facilitate the analyses of $\mathrm{HCHO}$ contents, due to the considerable surface area of the comminuted UF resin, it was necessary to modify the perforator method so that the analyses were performed on $5 \mathrm{~g}$ resin samples. The contents of $\mathrm{HCHO}$ 
Table 2 Properties of UF/pMDI adhesive mixture

Tablica 2. Svojstva smjese ljepila UF/pMDI

\begin{tabular}{|c|c|c|c|c|c|c|c|}
\hline $\begin{array}{c}\text { Type of mixture } \\
\text { Vrsta smjese }\end{array}$ & $\begin{array}{c}\text { Gel time at } \\
\mathbf{1 0 0}{ }^{\circ} \mathbf{C} \\
\text { Vrijeme } \\
\text { geliranja pri } \\
100{ }^{\circ} \mathrm{C}\end{array}$ & $\begin{array}{c}\text { No. 4 Ford } \\
\text { Cup viscosity } \\
\text { Viskoznost } \\
\text { prema Fordu }\end{array}$ & $\begin{array}{c}\text { Substances } \\
\text { leached with } \\
\text { water } \\
\text { Tvari isprane } \\
\text { vodom }\end{array}$ & $\begin{array}{c}\text { Absorbability } \\
\text { Sposobnost } \\
\text { apsorpcije }\end{array}$ & $\begin{array}{c}\text { Swelling } \\
\text { Bubrenje }\end{array}$ & $\begin{array}{c}\text { Activation } \\
\text { energy } \\
\text { Energija } \\
\text { aktivacije }\end{array}$ & $\begin{array}{c}\text { Content of } \\
\text { HCHO } \\
\text { Sadržaj } \\
\text { HCHO }\end{array}$ \\
\cline { 2 - 11 } & \multicolumn{2}{|c|}{$\mathrm{s}$} & 2.91 & 15.38 & 4.18 & 78.36 & 88.5 \\
\hline UF & 75 & 89 & 2.32 & 12.62 & 3.56 & 65.75 & 71.65 \\
\hline
\end{tabular}

* dry resin solids / suhe tvari smole

were determined in aqueous solutions by colorimetry with p-fuchsin.

Prior to FTIR analysis, all samples were vacuum dried in an exsiccator over $\mathrm{P}_{2} \mathrm{O}_{5}$. Samples were prepared by pelleting with $\mathrm{KBr}$, which is one of the best and most commonly applied preparation methods used for solids. In order to obtain pellets, a mixture of the tested substance and anhydrous $\mathrm{KBr}$ was prepared at a 1:50 weight ratio. Infrared spectra were recorded using a Fourier transform spectrophotometer within the wavelength range of $4000-500 \mathrm{~cm}^{-1}$.

Samples of polycondensed resin of $18 \mathrm{~mm}$ in length were prepared for determinations of absorbability and swelling in length. Calculations were made on the basis of measured increments in weight and length after $24 \mathrm{~h}$ soaking in water at $20 \pm 1^{\circ} \mathrm{C}$.

\section{RESULTS AND DISCUSSION}

\section{REZULTATI I RASPRAVA}

The results of analyses concerning properties of liquid and polycondensed UF resin/pMDi mixture are presented in Table 2, while testing results for properties of particleboard manufactured with such modified urea resin were presented in a study by Dziurka and Mirski (2010).

Analyses conducted on properties of particleboards, presented in the cited study, showed that even boards manufactured at pressing time reduced to $16 \mathrm{~s} /$ $\mathrm{mm}$ board thickness exhibited better properties than the reference board manufactured under identical conditions and resinated with pure UF resin. The increase in bending strength, modulus of elasticity and internal bond recorded under these conditions amounted to 32, 14 and $23 \%$, respectively. It should be particularly stressed that water resistance of these boards, mea- sured in the V100 test, practically met the limit specified in the standard for P3 boards $\left(0.09 \mathrm{~N} / \mathrm{mm}^{2}\right)$.

Such a considerable improvement in properties of manufactured boards is confirmed by testing results for properties of the UF resin/pMDi mixture. A mean decrease, amounting to $16 \%$, in absorbability and swelling in thickness observed for the polycondensed resin mixture may indicate the reaction of hydrophilic hydroxymethylene groups of UF resin with pMDI, thus reducing its susceptibility to hydrolysis. This is confirmed by a considerable improvement of water resistance in manufactured boards (Dziurka and Mirski, 2010). This course of polycondensation in UF resins modified with pMDI is also indicated by the results of analyses of their formaldehyde contents. It is a well-known fact that free formaldehyde is released as a result of hydrolysis of hydroxymethylene bonds in resin. Blockage of these groups, either through their reaction with NCO groups or by direct substitution to the aromatic ring, will result in its lower content in resin. In turn, as it results from data presented in Table 1, the content of $\mathrm{HCHO}$ as previously in UF resin with a $10 \%$ addition of pMDI is lower by approx. $20 \%$ in relation to free UF resin, which confirms the above mentioned line of reasoning.

While the increase in hydrophobicity of hybrid resins and the related reduction of formaldehyde emissions are evident, there is still no insight into the mechanism of the reaction occurring during the mixing of both types of resins (Pizzi and Walton, 1992; Pizzi et al., 1993; Simon et al., 2002a, 2002b; Despres et al., 2006; Wieland et al., 2006, 2007). Simon et al. (2002a, $2002 \mathrm{~b}$ ) proved that in the acid environment required for curing urea resin, methylene bridges are dominant structures, formed as a result of direct substitution of isocyanates of the methylol groups in UF resin to the benzene ring (Figure 1).

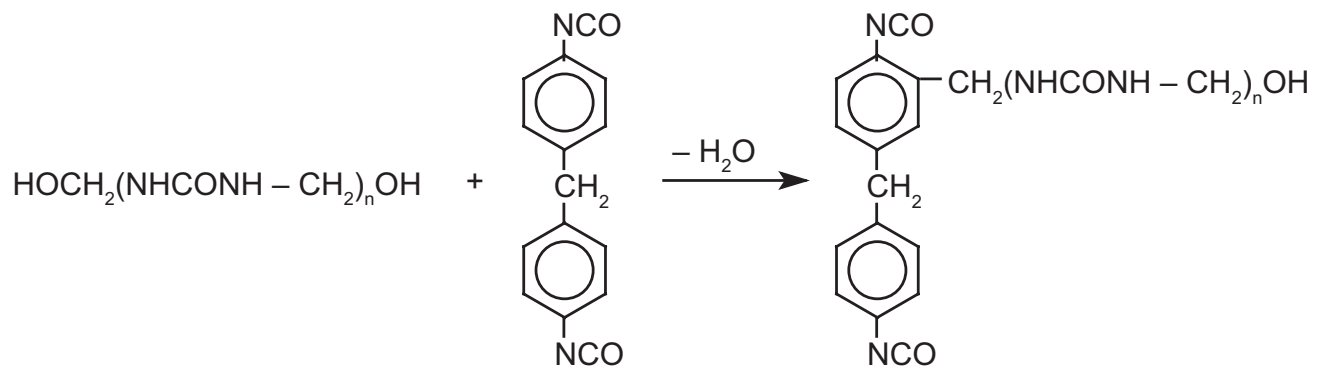

Figure 1 Reaction scheme of pMDI with methylol groups of UF resin

Slika 1. Shema reakcije pMDI-ja s metilol grupama UF smole 


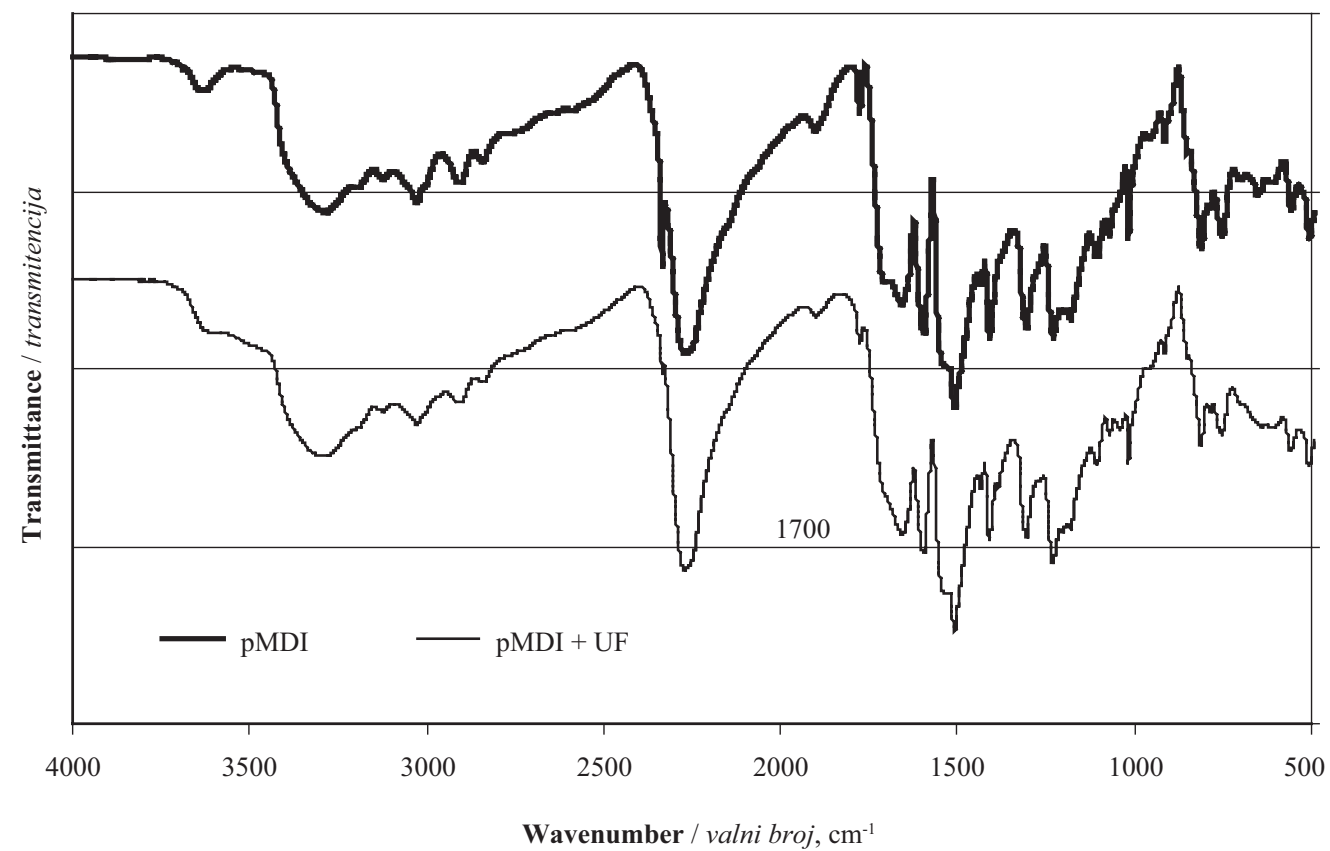

Figure 2 IR spectra of UF resin modified with pMDI

Slika 2. IR spektar UF smole modificirane pMDI-jem

In turn, urethane bridges, so characteristic of the alkaline PF resin cured in the presence of pMDI, are also formed, but in much lower amounts.

However, in view of the overlapping characteristic bands, the recorded spectrum (Figure 2) of the hybrid UF resin/pMDI does not show clearly which of the above mentioned structures predominates. One of the characteristic bands at a wavelength of $1700 \mathrm{~cm}^{-1}$ is ascribed to vibrations of the carbonyl group of $\mathrm{C}=\mathrm{O}$ in the multisubstituted ureas. It may originate both from the cured UF resin [- $\left.\mathrm{CH}_{2}-\mathrm{NHCON}\left(-\mathrm{CH}_{2}-\right)_{2}\right]$ and polyureas formed as a result of reactions of MDI with $-\mathrm{CH}_{2} \mathrm{OH},-\mathrm{NH}_{2}$ or -NH- groups of UF resin, or even from the carbonyl group of urethane bridges as a result of reactions between $-\mathrm{N}=\mathrm{C}=\mathrm{O}$ and $-\mathrm{CH}_{2} \mathrm{OH}$ groups.
Although the mechanism of the reaction between both types of resin is not clear enough, there is no doubt that the introduction of pMDI to liquid UF resin results in an increase in its reactivity, manifested in a shortening of gel time (Table 2) and a reduction of activation energy of the polycondensation process (Figure 3, Table 2).

\section{CONCLUSION 4. ZAKLJUČAK}

To sum up, the analyses performed on properties of amine resin modified with pMDI indicated that its introduction to liquid UF resin already at $10 \%$ results in an increase in its reactivity, manifested in a shorten-

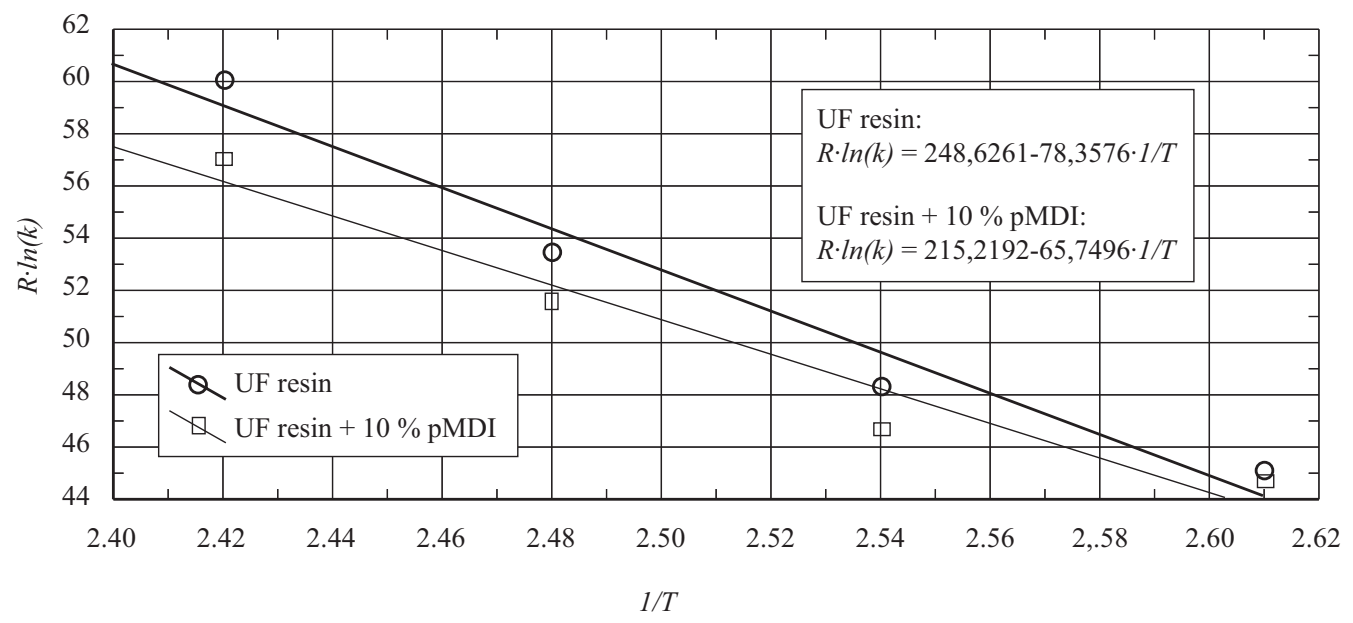

Figure 3 Reaction rate constant depending on temperature of pure UF resin and UF/pMDI glue mixture gel time

Slika 3. Ovisnost konstante brzine reakcije o temperaturi čiste UF smole i o vremenu želiranja smjese ljepila UF/pMDI 
ing of gel time and a reduction of activation energy of the polycondensation process. Moreover, the analyses performed on properties of polycondensed resin showed that, thanks to the modification with pMDI, its hydrophobicity is improved considerably, as reflected in a reduction of absorbability and swelling in length of cured resin.

\section{REFERENCES}

\section{LITERATURA}

1. Cremonini, C.; Pizzi, A., 1999: Field weathering of plywood panels bonded with UF adhesives and low proportions of melamine salts. Holz a. Roh- u. Werkst. 57(5): 318. http://dx.doi.org/10.1007/s001070050350

2. Cremonini, C.; Pizzi, A.; Zanuttini, R., 1996: MUF upgrading and phenol substitution by tannin in PMUFs. Holz a. Roh- u. Werkst. 54(4): 282. http://dx.doi.org/10.1007/s001070050184

3. Cremonini, C.; Pizzi, A.; Tekely, P., 1996a: Improvement of PMUF adhesives performance for fireproof plywood. Holz a. Roh- u. Werkst. 54(1): 43-47. http://dx.doi.org/10.1007/s001070050130

4. Cremonini, C.; Pizzi, A.; Tekely, P., 1996b: Influence of PMUF resins preparation method on their molecular structure and performance as adhesives for plywood. Holz a. Roh- u. Werkst. 54(2): 85-88. http://dx.doi.org/10.1007/s001070050142

5. Despres, A.; Pizzi, A.; Delmotte, L., 2006: ${ }^{13} \mathrm{C}$ NMR investigation of the reaction in water of UF resins with blocked emulsifiable isocyanates. J. Appl. Polym. Sci. 99(2): 589-596. http://dx.doi.org/10.1002/app.22498

6. Dziurka, D.; Łęcka, J., 2004: The effect of methods of introducing acrylic emulsions grafted with acetoacetyl groups on the properties of particleboards. J. Appl. Polym. Sci. 91(4): 2256-2264.

http://dx.doi.org/10.1002/app.13356

7. Dziurka, D.; Mirski, R., 2010: UF-pMDI hybrid resin for waterproof particleboards manufactured at a shortened pressing time. Drvna Industrija 61(4): 245-249. http:// hrcak.srce.hr/file/93653

8. Kamoun, C.; Pizzi, A., 1998: Performance effectiveness of addition to UF of melamine salts vs. melamine alone in MUF adhesives for plywood. Holz a. Roh- u. Werkst. 56(1): 86 http://dx.doi.org/10.1007/s001070050270

9. Lei, H.; Pizzi, A.; Guanben, D., 2006: Coreacting PMUF/ isocyanate resins for wood panel adhesives. Holz a. Rohu. Werkst. 64(2): 117-120. http://dx.doi.org/10.1007/s00107-005-0044-1

10. Mansouri, H. R.; Pizzi, A.; Leban, J. M., 2006: Improved water resistance of UF adhesives for plywood by small pMDI additions. Eur. J. Wood Prod. 64(3): 218-220. http://dx.doi.org/10.1007/s00107-005-0046-Z

11. Osman, Z.; Pizzi, A.; Kantner, W.; Triboulot, M. C., 2005: PUF panel adhesives dopped with additional urea and reinforced by isocyanates. Holz a. Roh- u. Werkst. 63(1): 53-56. http://dx.doi.org/10.1007/s00107-004-0529-3

12. Pizzi, A.; Valenzuela, J.; Westermeyer, C., 1993: Nonemulsifiable, water-based, mixed diisocyanate adhesive systems for exterior plywood. Part II. Theory application and industrial results. Holzforschung 47: 68-71. http://dx.doi.org/10.1515/hfsg.1993.47.1.68

13. Pizzi, A.; Walton, T., 1992: Non-emulsifiable, waterbased, mixed diisocyanate adhesive system for exterior plywood. Part I. Novel reaction mechanisms and their chemical evidence. Holzforschung 46(6): 541-547. http://dx.doi.org/10.1515/hfsg.1992.46.6.541

14. Prestifilippo, M.; Pizzi, A., 1996: Poor performance of PMUF adhesives prepared by final coreaction of a MUF with a PF resin. Holz a. Roh- u. Werkst. 54(4): 272. http://dx.doi.org/10.1007/s001070050180

15. Prestifilippo, M.; Pizzi, A.; Norback, H.; Lavisci, P., 1996: Low addition of melamine salts for improved UF adhesives water resistance. Holz a. Roh- u. Werkst. 54(6): 393-398. http://dx.doi.org/10.1007/s001070050208

16. Proszyk, S.; Krystofiak, T.; Kasprzyk, H.; Jóźwiak, M., 1996: Studies on the kinetics of the gelation process of the urea-formaldehyde glues. Forestry and Wood Technology 47: 47-54.

17. Simon, C.; George, B.; Pizzi, A., 2002a: Copolymerization in UF/pMDI adhesives networks. J. Appl. Polym. Sci. 86(14): 3681-3688. http://dx.doi.org/10.1002/app.11330

18. Simon, C.; George, B.; Pizzi, A., 2002b: UF/pMDI wood adhesives: Networks blend versus copolymerization. Holzforschung 56(3): 327-334. http://dx.doi.org/10.1515/HF.2002.052

19. Tomita, B.; Hse, Ch. Y., 1992: Cocondensation of urea with methylolphenols in acidic conditions. J. Polym. Sci. Part A. Polymer Chemistry 30(8): 1615-1624. http://dx.doi.org/10.1002/pola.1992.080300814

20. Tomita, B.; Ohyama, M.; Hse, Ch. Y., 1995: Synthesis of phenol-urea-formaldehyde cocondensed resins from UF concentrate and phenol. Holzforschung 48(6): 522-526. http://dx.doi.org/10.1515/hfsg.1994.48.6.522

21. Wang, X. M.; Riedl, B.; Christiansen, A. W.; Geimer, R. L., 1995: The effect of temperature and humidity on phenol formaldehyde resin bonding. Wood Sci. Technol. 29: 253-266. http://dx.doi.org/10.1007/BF00202085

22. Weinstabl, A.; Binder, W. H.; Gruber, H.; Kantner, W., 2001: Melamine salts as hardeners for urea formaldehyde resins. J. Appl. Polym. Sci. 81(7): 1654-1661. http://dx.doi.org/10.1002/app.1596

23. Wieland, S.; Pizzi, A.; Grigsby, W.; Warnes, J.; Pichelin, F., 2007: Microcrystallinity and colloidal peculiarities of UF/isocyanate hybrid resins. J. Appl. Polym. Sci. 104(4): 2633-2636. http://dx.doi.org/10.1002/app.24757

24. Wieland, S.; Pizzi, A.; Hill, S.; Grigsby, W.; Pichelin, F., 2006: The reaction in water of UF resins with isocyanates at short curing times: $\mathrm{A}^{13} \mathrm{C}$ NMR investigation. J. Appl. Polym. Sci. 100(2): 1624-1632. http://dx.doi.org/10.1002/app.23679

25. Zhao, C.; Pizzi, A., 2000: Hot postcuring improvement of MUF-bonded particleboards and its temperature forecasting model. Eur. J. Wood Prod. 58(5): 307-308. http://dx.doi.org/10.1007/s001070050434

\section{Corresponding address:}

\section{Assistant Professor DOROTA DZIURKA, Ph.D.}

Poznań University of Life Sciences

Faculty of Wood Technology

Department of Wood-Based Materials

Wojska Polskiego 38/42

60-627 Poznań, POLAND

e-mail: ddziurka@up.poznan.pl 